\title{
A NEW SPECIES OF IBITERMES (ISOPTERA, TERMITIDAE) FROM THE ATLANTIC FOREST, NORTHEASTERN BRAZIL
}

\begin{abstract}
Alexandre Vasconcellos ${ }^{1}$
ABSTRACT

The sterile castes of Ibitermes inflatus sp. nov. from Rio Tinto, State of Paraíba, Brazil are described and illustrated. This is the first record of a species of Ibitermes from the Brazilian northeast and from the Atlantic Forest biome. The absence of ridges in the molar plate of the left mandible and the presence of granules of sand and silt mixed with organic matter in advanced stage of decomposition in the digestive tube of workers suggest that the species is a typical humus feeding termite.
\end{abstract}

KEYWORDS. Isoptera, Nasutitermitinae, Taxonomy, Atlantic forest, Neotropical.

\section{INTRODUCTION}

The termite diversity in some ecosystems of the Brazilian northeast, such as the Atlantic forest, the upland humid forest (Brejos de altitude) and the semi-arid (Caatinga) are poorly known (BANDEIRA \& VASCONCELLOS, 1999). BANDEIRA et al. (1998) estimated that in fragments of the Atlantic forest, in João Pessoa, State of Paraíba, Brazil, about $65 \%$ of the species collected in 0.4 ha are new to science.

The genus Ibitermes was proposed by FoNTES (1985), originally including just I. curupira Fontes, 1985, collected in a Pinus elliotti Engelm. plantation in the southeast of Brazil. CoNSTANTINO (1990) described I. tellustris, collected in primary rain forest in the west of the Brazilian Amazonia. The molar plate of mandibles suggests that the two species feed on humus.

The soldier and worker caste of Ibitermes inflatus sp. nov. from the Atlantic forest of the Brazilian northeast are described and illustrated.

\section{MATERIAL AND METHODS}

Measurements presented: length of head to the side base of mandibles; length of head to the tip of nasus; lengh of nasus; width of head; height of head excluding the postmentum and the nasus; width of pronotum; length of posterior tibia. These measures respectively correspond to RoonwaL (1970) numbers 5, 12, 13, 17, 21, 68 and 85. The left mandible index of workers follows EMERSON (1960): La/L1, where La is the distance separating the apical tooth from the fused first and second marginal, and L1 is the distance separating the fused first plus second marginal from the third. Five worker alimentary canals were dissected and the intestinal content was

1. Departamento de Sistemática e Ecologia, Centro de Ciências Exatas e da Natureza, Universidade Federal da Paraíba, 58059-900 João Pessoa, Paraíba, Brazil. (avasconcellos@dse.ufpb.br) 
investigated under stereomicroscope. The terminology adopter for "bristles" and "hairs" of the soldiers and workers follows EMERSON (1925), and the description of the coloration follows SANDS (1965).

\section{Ibitermes inflatus sp. nov.}

(Figs. 1-9)

Type material. BRAZIL, Paraíba: Rio Tinto, Reserva Biológica Guaribas (06 $48^{\prime} \mathrm{S}$; $\left.35^{\circ} 06^{\prime} \mathrm{W}\right)$, 19.VI.2000, A. Vasconcellos col.: holotype (soldier, Museu de Zoologia, Universidade de São Paulo, MZSP 11194); paratypes (soldiers and workers) (Universidade Federal da Paraíba, João Pessoa, UFPB 1330) and in the collection L. R. Fontes, São Paulo (LRFC 1958).

Etymology. The specific adjective derives from the latin inflatus, that means inflated as a reference to the strongly developed postclypeus of the soldier and worker castes.

Imago. Unknown.

Soldier (figs. 1-4, tab. I). Head capsule yellow to yellow-brown; antennae with first and second articles yellow, remaining yellow-brown; postclypeus pale brown; posmentum and labrum yellow; base of nasus and mandibles yellow-brown, middle of nasus brown, apex sepia brown; pronotum yellow-white; remainder of body white. Head with few bristles (fig. 1). Postclypeus with 4 bristles, 2 in the apex and 2 in the sides. Pronotum with 10-14 bristles on the anterior margin, 3-6 on the posterior margin and 25-30 on the surface. Meso- and metanotum with bristles on the posterior margins. Tergites and sternites with bristles on the posterior and anterior margins, and many hairs on the surface, most oriented backwards.

Head capsule slightly elongated, sides convex and somewhat bulging in the middle, posterior margin slightly convex; nasus conical, tip clearly surpasses the apex of mandibles; in profile, nasus projecting slightly upwards; postclypeus very strongly inflated and reaching the middle of the nasus in dorsal view, longitudinal median line of postclypeus clearly depressed; labrum oriented downward and hidden by the postclypeus in dorsal view; posmentum moderately elongated with sides convex; mandibles robust and without marginal teeth, curved inwards and downwards; antennae with 14 articles: II longer than III, IV and V, which are almost the same length; anterior margin of pronotum incised in the middle, posterior margin slightly convex in the middle. Tibial spurs 2:2:2. Anterior coxa without outside projection.

Worker (figs. 5-9). Apparently monomorphic. Head and antennae yellow-white; thorax white; abdominal sclerites transparent, allowing the visualization of the intestinal content. Head with about 7-10 bristles on posterior and lateral parts, and 6-15 short hairs (not microscopic) mainly around the fontanelle. Postclypeus with about 4 bristles ( 2 on anterior margin and 2 on the middle) and a few hairs. Pronotum with 2-4 bristles on the anterior margin, 2-4 on the posterior margin, and short to long hairs scattered on the surface. Meso- and metanotum with long hairs to bristles sparse on the posterior margin. Chaetotaxy of the abdomen as in the soldier. Postclypeus strongly inflated. Mandibles (fig. 2). Left mandible index 1.1. Antennae with 14 articles: II longer than III and IV. In some specimens, the third article is partially divided. Abdomen oval; intestine with the mesenteric band of the mixed segment originated in the dorsal side of the mesenteric arch and then twisted, so that the apex of the mesenteric band ends ventrally and posteriorly in the mixed segments.

Comparisons. The soldier of I. inflatus is distinguished from those of others Ibitermes by the nasus that clearly surpasses the apex of the mandibles and by the head capsule with distinct convex sides, swollen in the middle. It is larger than the soldier of I. tellustris 

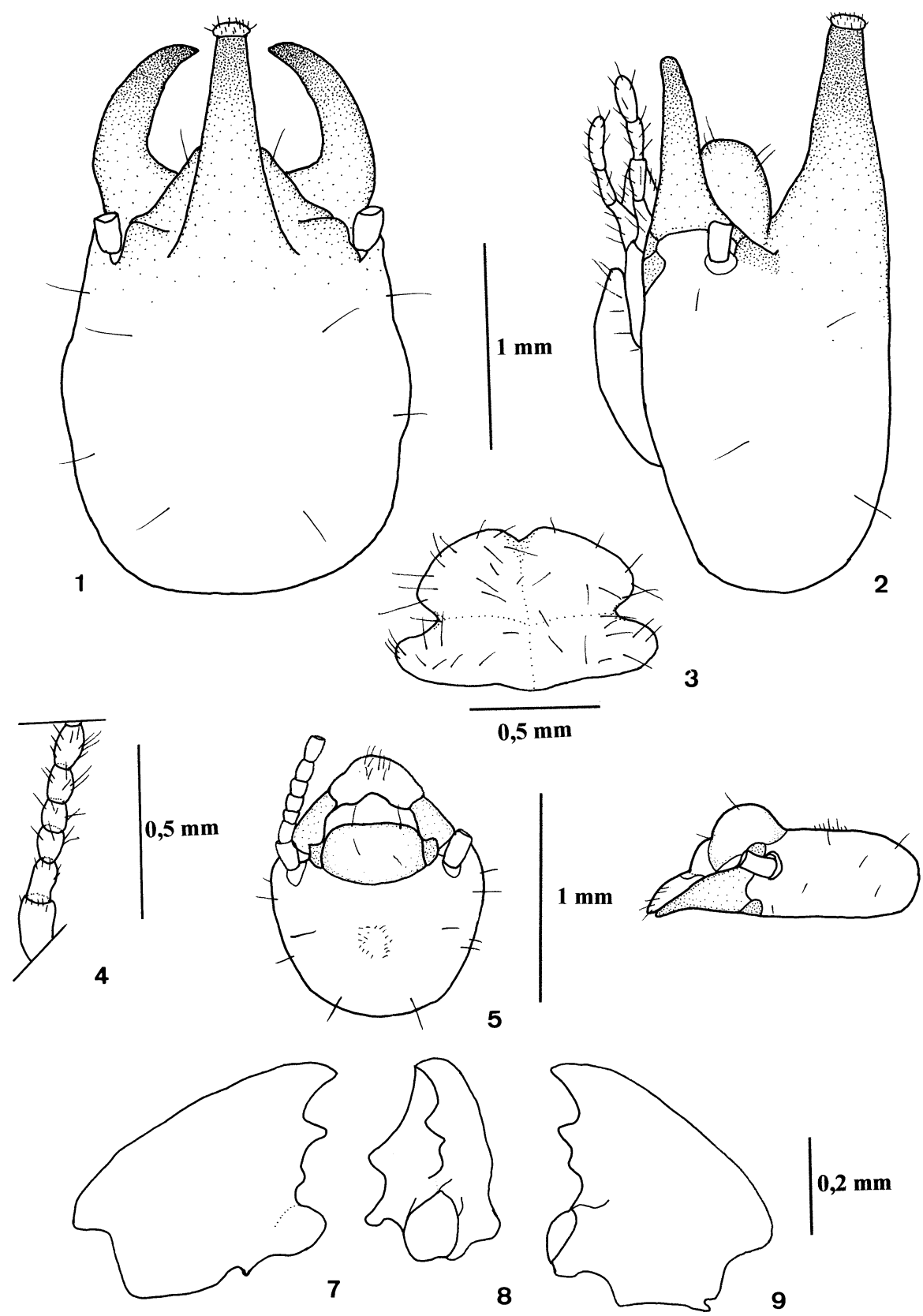

Figs. 1-9. Ibitermes inflatus sp. nov., soldier: 1, head, dorsal view; 2, profile; 3, pronotum, dorsal view; 4, detail of antennae. Worker: 5 , head, dorsal view; 6 , profile; mandibles: 7 , left; 8,9 right. 
Table I. Measurements (in mm) of 15 soldiers of Ibitermes inflatus sp. nov.

\begin{tabular}{llll}
\hline Measurements & Range & Mean + SD & Holotype \\
\hline Length of head to tip of nasus & $2.66-2.88$ & $2.77+0.06$ & 2.73 \\
Lengh of nasus & $0.91-1.08$ & $1.01+0.05$ & 0.94 \\
Length of head to side base of mandibles & $1.65-1.79$ & $1.72+0.06$ & 1.77 \\
Width of head & $1.50-1.67$ & $1.58+0.05$ & 1.62 \\
Height of head & $1.16-1.23$ & $1.19+0.02$ & 1.17 \\
Width of pronotum & $0.94-1.02$ & $0.97+0.02$ & 1.01 \\
Length of hind tibia & $1.25-1.35$ & $1.31+0.03$ & 1.31 \\
\hline
\end{tabular}

(Constantino, 1990) and smaller than that of I. curupira (Fontes, 1985). The soldier of $I$. curupira has less bristles on the anterior margin and surface of the pronotum, and the sides of the head are weakly convex. The soldier of I. tellustris does not have an inflated postclypeus, the head has more bristles and its the sides are almost parallel.

Biology. Ibitermes inflatus is rare in the type locality. The specimens lived in diffuse galleries in the forest soil, with about $1 \mathrm{~cm}$ of diameter and 5-35 $\mathrm{cm}$ bellow the surface, but they may be occasionally found up to $40 \mathrm{~cm}$. Analysis of the alimentary content of the worker digestive tube showed granules of sand and silt mixed with organic matter in advanced stage of decomposition. The mandibles of the worker, without ridges in the molar plate and with a large apical tooth, suggest that I. inflatus is a humus feeding termite.

Acknowledgments. To Dr. Adelmar G. Bandeira (UFPB) for comparing specimens in the MZSP; to Dr. Luiz R. Fontes (Superintendência de Controle de Endemias, São Paulo) and Dra. Eliana M. Cancello (MZSP) for the critical reading of the manuscript; to Dr. Martin L. Christoffersen, for revising the English version of the text; and to CAPES for the financial support.

\section{REFERENCES}

Bandeira, A. G.; Pereira, J. C. D. et al. 1998. Composição da fauna de cupins (Insecta, Isoptera) em área de Mata Atlântica em João Pessoa, Paraíba, Brasil. Revta Nordestina Biol., João Pessoa, 12(1/2):9-17.

Bandeira, A. G. \& Vasconcellos, A. 1999. Estado atual do conhecimento sistemático e ecológico sobre os cupins (Insecta, Isoptera) do nordeste brasileiro. Revta Nordestina Biol., João Pessoa, 13(1/2):37-45.

Constantino, R. 1990. Two new species of termites (Insecta, Isoptera) from western Brazilian Amazonia. Bolm Mus. para. Emílio Goeldi, Sér. Zool., Belém, 6(1):3-9.

Emerson, A. E. 1925. The termites of Kartabo, Bartica District, British Guiana. Zoologica, New York, 6:291459.

- 1960. New genera of termites related to Subulitermes from the Oriental, Malagasy, and Australian regions (Isoptera, Termitidae, Nasutitermitinae). Am. Mus. Novit., New York, (1986):1-28.

FonTES, L. R. 1985. New genera and new species of Nasutitermitinae from the Neotropical Region (Isoptera, Termitidae). Revta bras. Zool., São Paulo, 3(1):7-25.

Roonwal, M. L. 1970. Measurements of termites (Isoptera) for taxonomic purposes. J. zool. Soc. India, Calcutta, 21:9-66.

SANDS, W. A. 1965. A revision of the termite subfamily Nasutitermitinae (Isoptera, Termitidae) from the Ethiopian region. Bull. Br. Mus. nat. Hist., Ent. Suppl., London, 4:1-172.

Aceito em 04.10.2001; aceito em 12.04.2002. 